\title{
RESEARCHING EIGHTEENTH-CENTURY FRAUD IN THE OLD BAILEY: REFLECTIONS ON COURT RECORDS, ARCHIVES, AND DIGITISATION
}

\begin{abstract}
This article seeks to provide reflection and guidance to researchers of fraud in Britain during the eighteenth and nineteenth centuries. This reflection explains two reasons why there is a dearth of historical research into fraud offences. These reasons are ontological and methodological. The definitions and laws of fraud are complex and difficult to identify, and one of the most accessible court archive, the Old Bailey Sessions Papers (the Proceedings), needs to be treated with caution by the researcher of fraud. This article uses the in-depth historiography surrounding the Proceedings and applies this to the research of fraud offences which, this article argues, require a particular methodological approach.
\end{abstract}

Keywords: Fraud; Old Bailey; Digitisation; Legal History; Methodology.

\section{INTRODUCTION}

The history of fraud and the criminalisation of financial behaviour is an underresearched subject amongst lawyers and historians (Robb 1992, 6). There exists some excellent research on financial crime, both historic and contemporary such as: (Sindall 1983, 23-40; Tomasic 2011, 7-31; Levi 1987; Foreman-Peck 1995). In recent years, academics such as James Taylor and Sarah Wilson have been producing invaluable research on nineteenth-century corporate fraud and banking and joint-stock companies (Wilson 2006, 1073-1090; Taylor 2006). Both Taylor and Wilson frame their analysis around the opportunities to commit fraud created by the joint-stock company (Wilson 2006, 1073-1090; Taylor 2006). However, the research into fraud in earlier periods remains sparse.

This article will address two reasons as to why fraud and financial crime are under-researched in crime and legal history circles, these being ontological and methodological. The offences themselves are ontologically problematic and, more significantly for this article, there are significant methodological challenges with the court and legal records which form useful archives for the research of historic fraud. In keeping with the purposes of this edition of Acta Universitatis Lodziensis. Folia Iuridica, this article will reflect on some of the barriers and hurdles to researching

\footnotetext{
*Lancaster University Law School, c.griffiths3@lancaster.ac.uk.
} 
fraud and financial crime in the eighteenth century. In particular, the unique quasiofficial court records of London's Central Criminal Court, the Old Bailey Sessions Papers (The Proceedings) will be analysed from within a heretofore unconsidered framework, a fraud context. As one of the most voluminous and valuable archives pertaining to courts within London, the financial centre of Britain, the Proceedings are a rich source for researchers of fraud and financial crime.

This article will consider three issues. First, the creators and purposes of the Proceedings will be evaluated. In addressing who created this archive and why, the researcher of fraud is better placed to critically assess the information held within. Second, the matter of the relatively recently digitisation of the Proceedings and the consequences this process has for the researcher of fraud. And finally, how the researcher of fraud can locate offences of financial crime within the Proceedings along with the methodological considerations such as opportunities for quantitative research of fraud.

The analysis within this article will hopefully provide some guidance to those interested in researching eighteenth and nineteenth century fraud. It shall demonstrate how the historical investigation of fraud offences requires specific consideration of these offences themselves, of their ontological boundaries, of the lexicon associated with these offences, and how they can be researched within a large digitised archive such as the Proceedings. Additionally, this article will, for the first time in the literature of the Old Bailey, clearly demonstrate that the Proceedings failed to report a number of fraud trials heard within the Court and consequently, some reflections on the perils of quantitative research of the Proceedings will be presented.

\section{THE OLD BAILEY PROCEEDINGS: USE AS AN HISTORICAL SOURCE FOR THE RESEARCHING FRAUD}

In considering the prosecution of fraud during the eighteenth and nineteenth centuries, the most detailed surviving source of criminal trials is the Old Bailey Proceedings ('the Proceedings'). These Proceedings are the best accounts we have of the administration of criminal justice in England before the mid-nineteenth century (Langbein 1978, 271) and as such, any research surrounding criminal trials during this period must have at its bedrock, the Proceedings. However, the Proceedings are not without their limitations and undertaking any legal or crime history research, based solely upon the Proceedings should be avoided (Langbein 1978, 271).

\section{The Old Bailey Proceedings: an Overview}

The Proceedings are a written report of trials heard in the Old Bailey between 1676 and 1913. They were written eight times a year, one issue for each sitting of the Old Bailey (Hitchcock, Shoemaker 2006, 193). Supposedly, barring two brief 
periods of time, absolutely all cases appear within the Proceedings (Langbein 1978, 272; Shoemaker 2008, 559-580; Gallanis 2006, 159-173; Devereaux 1996, 466-503). These two exceptions are the first ten years of the life of the Proceedings when not all cases were covered (Archer 2014, 264), and second, between 1790 and 1793 when only cases which resulted in conviction were reported (Devereaux 1996, 481).

It is at this very early stage of considering the Proceedings as an archive that the first methodological pitfalls become apparent. Research carried out for the purposes of my doctoral thesis (Griffiths 2017) has revealed a number of cases reported elsewhere, which almost certainly appeared at the Old Bailey, but which are missing from the Proceedings. The case of $R v$ Vincent Wright, Anne Fagan and William Elson (National Archive records: T38/675) is well documented in the summary court accounts, and details are given of the trial at the Old Bailey. However, no reference to this case appears in the Proceedings. A further case, The King $v$ Benjamin Lara ([1794] 2 Leach 647168 E.R. 425), was a Crown Case Reserve case, the report of which clearly states the matter to have been initially tried at the Old Bailey. Again, no reference to this trial appears within the Proceedings. These findings illustrate that, contrary to common belief, the Old Bailey Proceedings do not record all cases heard at the Old Bailey.

Had it not been for a methodology which undertook a close reading of all Proceedings cases categorised as fraud between 1760 and 1820, which were triangulated against a range of court records, not just the Old Bailey, such missing cases would not be identified. Such a methodological approach has not before been systematically undertaken, particularly with regard to fraud offences. Due to the digitisation of the Proceedings, research on the Old Bailey has focused on the big data possibilities of such a resource and perhaps it is unsurprising that it took this form of research, the closer reading of all indictments relating to one form of offence, to reveal missing trial reports within the Proceedings. In slicing through vast amounts of data to focus upon the prosecution of a specific offence, a more nuanced picture of the accuracy and completeness of the Proceedings can emerge. Equally significantly, where court and official records from other courts and offices are used to illustrate a bigger and more detailed picture of the prosecution of fraud, this cross-checking allows for the identification of missing trials. The first finding of these reflections is that the Proceedings should not be analysed in isolation as additional records have revealed the missing cases from the Proceedings.

It is perhaps not possible to estimate the number of trials missing from the Proceedings. The complimentary records explored alongside the Proceedings are themselves incomplete (Griffiths 2017). It is likely that cases were missed for reasons beyond the substance or procedure of the offence itself. These reasons included the nature of the reporting itself and the purpose of the Proceedings. 


\section{Creators of the Proceedings: Publishers and Shorthand Writers}

In order to explore the reliability of an historical source, it is essential to ascertain the creator of the source. From the inception of the Proceedings, the Lord Mayor of London approved of the publication (Archer 2014, 264) but on the condition that the publisher paid the Lord Mayor for the privilege (Devereaux 1996, 468). After 1775, the licence for the Proceedings was transferred from the Lord Mayor to the City of London and the publisher did not have to pay to publish the Proceedings (Devereaux 1996, 482). By 1778, the City of London was subsidising the publication of the Proceedings on the condition that they gave a 'true, fair and perfect narrative' of the trials (Devereaux 1996, 468). This requirement greatly extended the length of the Proceedings, sometimes resulting in one edition having a number of volumes. The length of the Proceedings also increased in the nineteenth century for a range of reasons, partly because of a growing population and partly as trials became more complicated. This is not to say that the Proceedings were, to any extent, a verbatim account. The narratives of the trials were taken down by shorthand writers and copy (the text) was then handed to the editor to decide what to include within the particular edition. For practical as well as political, social and commercial purposes, the details of the trials reported are highly selective.

The greater issue for the researcher of fraud is what the writers chose to leave out of their reports (Langbein 1999, 319). As stated above, these political, commercial, and social considerations were far more influential upon what writers chose to include in their reports than any practical limitation. However, there is suggestion that writers did not work alone when attending the Sessions and rather, at least pairs, if not teams of writers would share the burden between them thereby increasing the possibility of capturing all details of the trial.

One glaring omission from the Proceedings, which will be discussed in more detail below, is the request by editors that legal and procedural argument be ignored by the shorthand writers (Langbein 1978, 264). This was for a range of reasons including not wishing to lose the public's interest by including drier material of the trials and also the belief that revealing too much about criminal processes could act as a guide to the more cunning criminal (Devereaux 1996, 492). Details of legal or procedural matters were omitted for a non-lawyer reading public in the belief that they would be too technical or boring (Gallanis 2006, 161). Perhaps a more practical explanation might be the limited role of lawyers in the criminal trial until 1836 when barristers were allowed, as of right, to represent prisoners (Griffiths 2014, 28). This alienation of lawyers from criminal litigation naturally extended to their role in the compiling and publishing of criminal trial materials, including the Proceedings (Langbein 1978, 264). Consequently, the tone and content of the Proceedings is lacking in legal detail and focus. This is problematic for legal historians occupied with legal issues such as procedure or wider legal argument. 


\section{The Functions of the Proceedings}

The purpose of the Proceedings reveals more about the historical use of this archive and explains which information the researcher can expect to find, and which information is most likely lacking. Throughout the life of the Proceedings, these reports had a range of functions. These functions depended on the aims of the publisher, the political climate of the day and the readership. The Proceedings needed to be financially viable as a commercial enterprise, they played a procedural role in that they were used for appellant and sentencing purposes, and as a semi-regulated publication the Proceedings inevitably played a political role in the wider discourses surrounding criminal justice. All of these functions effect how the researcher should read this source.

\section{Commercial Venture}

From the publisher's perspective, the Proceedings were a commercial venture like any other newspaper or pamphlet. The 1770s saw a collapse in the commercial viability of the Proceedings, as the number of newspapers grew and these newspapers increasingly published crime news. This competition may explain why the publishers so readily accepted subsidies from the City of London in the 1770s. Whilst one printer of the Proceedings in 1727 claimed the Proceedings were not 'to please the vulgar part of the town with buffoonery, this not being a paper of entertainment' (detailed in Shoemaker 2008, 564).

The publication of the Proceedings required a careful balancing of differing aims and objectives. Clearly, the Proceedings needed to appeal to the general public and needed to be entertaining. Consequently, sensational and shocking cases relating to murder, sodomy and rape would be expected to be well reported (Archer 2014, 263). As today, cases of lethal violence received more attention and the Proceedings detail these more than other offences (King 2009, 91). However, as today, murder was relatively rare and thus, other more shocking offences which might interest the public, were focused upon (King 2009, 91). The selection of the trials has been attributed to the sentencing of the offence rather than because of the actual crime; capital offences received more press coverage than noncapital offences (King 2009, 91). Consequently, trials of forgers and arsonists received much coverage as forgery in particular attracted higher execution rates (McGowen 2007).

A further significant shortcoming of the Proceedings is the way in which trials were condensed. John Langbein has rested great faith in the completeness of the Proceedings but he overlooks the attention and detail given to some offences over others. Shoemaker has raised grave, and well-founded concerns, that in every sessions, three to six days of trials were being compressed into eight to twenty four pages (Shoemaker 2008, 560). Such compression leads to a false impression of the length of trials, or the severity with which such offences were 
perceived by the courts. This physical compression of the Proceedings perhaps goes some way to explaining why some fraud cases were missed wholesale from the record.

\section{Procedural Tool}

Between at least 1775 and 1837, the Proceedings played a procedural role in the administration of justice. The Recorder of London used the Proceedings to construct lists of those convicts sentenced to death who were recommended for mercy to the monarch (Devereaux 1996, 472). These recommendations would be passed to the Privy Council before being presented to the monarch. Simon Devereaux has uncovered convincing evidence to suggest the use of the Proceedings by the Recorder in presenting his recommendations to the monarch; on several occasions direct page references to the Proceedings appear in the Recorder's notice (Devereaux 1996, 473). The Recorder used the Proceedings as a concise resource in order to get an overall picture of the particular trial he was considering (see Hay 2006). With eight sessions of the Old Bailey per year, the Recorder would have been under pressure to decide the cases in good time, partly to have one Sessions completed before the next began, partly because in the interim, the condemned prisoner was left languishing in prison (Devereaux 1996, 479). To the modern historian, and certainly to the modern lawyer, the use of the Proceedings as a tool for deciding any judicial matter is surprising. These reports were not verbatim and more significantly in this instance, did not contain any of the legal or procedural argument (Langbein 1978, 264). However, the Proceedings did contain evidence as to the character of the prisoner and it was this evidence which was used in deciding when to lessen the sentence.

The Proceedings also played a role in the limited appeals process of the day. There is evidence the Lord Chancellor used the Proceedings to inform himself of cases when deciding upon appeals (Devereaux 1996, 473). The Proceedings acted as guidance to the lower courts, in particular the summary courts. There is evidence of magistrates, particularly in Middlesex, regularly purchasing the Proceedings (Treasury Department Accounts - Hatton Garden - Police Office at National Archive ref T38/676). Whilst the use of the Proceedings to the magistrates is not apparent, assumedly one purpose would be to keep magistrates abreast of the work of the assize court and also, to monitor how cases referred to the Old Bailey by their offices were reported.

\section{Political Tool}

The Proceedings were a significant political instrument. During the 1770s, radicals such as John Wilkes, the Sheriff of London, called for more transparency in office and particularly in the courts. Wilkes believed that the administration of justice should be open to the public and took a range of steps to make the Old 
Bailey more transparent with some being more successful than others (Devereaux 1996, 486). Wilkes saw the Proceedings as the means by which the Old Bailey could be opened up and all trials could be reported (Devereaux 1996, 487). Thus, in 1775, the City of London began to publish the Proceedings on an authoritative footing and the requirement that the Proceedings be a 'fair, true and perfect narrative' description of trials was evidently fulfilling a number of requirements, including the purpose of making transparent the wheels of justice.

Of course, this opening up of the courts did not play a purely democratic role, it also acted to demonstrate to the populace the consequences of crime. It is perhaps no coincidence that the City of London authorities took over the publication. Clearly the City governors such as the Aldermen saw the importance of the criminal justice system and related publications, and the declaratory and normative role reporting of the criminal justice system could play (Griffiths 2017).

As a publication subsidised and guaranteed by the City authorities, it would be tempting to conclude that the Proceedings were no more than state propaganda. But this conclusion would be too simplistic (Devereaux 1996, 501). The government subsidised newspapers in much the same way as the City of London subsidised the publishing of the Proceedings and thus, some parallels can be drawn between the two. Historians largely agree that these subsidies were often too low to actually influence the commercial decisions of the publishers and the press regularly published material which opposed the government such as criminal trials which reflected the failings of the Bloody Code and the justice system as a whole (Devereaux 2007, 9). This is not to say however that the Proceedings were not influenced by the government or the City authorities. Whilst Devereaux suggests there to be 'no evidence that anyone in the City government ever sought to influence the Sessions Paper' (Devereaux 1996, 490), the Proceedings were not published entirely at the will of the editor. The Recorder had a lot of influence over the Proceedings and this partly explains why the reports became so uniform following the 1770s (Archer 2014, 266).

The Recorder and the City authorities wanted the Proceedings to reflect the successful functioning and justice of the criminal trial system. Examples of prisoners not showing due reverence for the law by arguing with judges or not taking the proceedings seriously were very rarely published within the Proceedings (Shoemaker 2008, 569). Moreover, details of any defence were frequently excluded or curtailed. One reason for this may be to give more of an impression of the clarity of the prosecution (Archer 2014, 266). In a time of private prosecutions, reflecting a smooth prosecution process may have acted to encourage more lay prosecutors to utilise the criminal courts. Perhaps more significantly, the focus upon the prosecution case may reflect how the authorities wished to legitimise the sentencing of criminals, which frequently involved their transportation and at times, execution. The speeches made by prisoners, asking the court to spare their lives, were very rarely reported. Again, this is most likely due to the desire of the 
authorities to justify the harsh sentences and Bloody Code which underpinned the criminal justice system (Shoemaker 2008, 570).

In 1790, the City of London requested that the Proceedings only publish the convictions secured at the Old Bailey and make no reference to the acquittals. This only lasted for three years before the publishers of the Proceedings demanded to be allowed to publish acquittals alongside convictions; the public were seemingly less interested in the Proceedings when they only listed the convictions (Devereaux 1996, 493). Why the Proceedings became less popular during this period of restriction is not entirely clear however. One explanation might be that the public became aware of this censoring and lost respect for the Proceedings as they knew them to be less than objective. There is certainly evidence that the public were actively involved in correcting the mistakes published in the Proceedings which is demonstrated by a number of corrections which had to published in relation to previous editions (Shoemaker 2008, 576). These public complaints reflect the reality that people were attending the Old Bailey to watch the trials and when the Proceedings published inaccurate details, they were quick to vocalise this. The decision to only publish the convictions of the Old Bailey must have been immediately apparent to a public who had witnessed a day of trials, an average of thirty-nine percent of which would have resulted in acquittal (Shoemaker 2008, 573).

Consequently, the researcher of fraud should be aware when using the Proceedings that these are a deeply valuable, but not unproblematic archive. Where possible, research of the Proceedings should be cross-referenced with other contemporary sources and where this is not possible, an awareness of the limitations of the archives is essential. Many of these limitations were recognised by those pioneering crime and legal historians who began researching the Proceedings in earnest from the 1970s. Those manually researching the Proceedings during this time had many additional methodological barriers given the scale of the records. The digitisation of the Proceedings opened up this treasured archive to the world and has made possible research which was impossible before. However, the contemporary or future researcher of fraud using the digitised version of the Proceedings also faces some methodological considerations.

\section{OLD BAILEY ONLINE (OBO): THE DIGITISATION OF THE PROCEEDINGS}

From 2000 to 2005, the Old Bailey Sessions Proceedings were digitised and this digitisation project, Old Bailey Online (OBO), has transferred all of the Proceedings onto a database. ${ }^{1}$ This process required the digitisation

\footnotetext{
${ }^{1}$ http://www.oldbaileyonline.org [Accessed $7^{\text {th }}$ January 2017].
} 
of 190,000 pages of the Proceedings alongside 4000 pages of the Ordinary's Accounts. ${ }^{2}$ In their entirety, the Proceedings consist of 134 million words (Archer 2014, 259).

\section{The Process of Digitisation}

Until digitisation, the Proceedings were recorded on microfilm and it is from these films that the OBO project obtained their data (Bradley, and Short 2005, 13). Due to the Proceedings being so inconsistent in layout and form, optical character read software could not be used, preventing any automated method for digitizing the Proceedings (for a detailed overview of another legal history digitization project see Eiseman et al. 2016). Instead, all of the content of the Proceedings was manually entered into the OBO database (Hitchcock, and Shoemaker 2006, 194). To limit error, all content was double rekeyed - entered into the database twice - and then the two versions were checked against each other using recognition software (Hitchcock, and Shoemaker 2006, 194). Errors cannot be wholly eradicated through this method, partly because of the human element involved in the transcription of the Proceedings. However, for every paper, a link to the original image of the report is attached. This is designed to allow users to check and confirm the text themselves (Hitchcock, and Shoemaker 2006, 199). If users identify an error in the transcription, they are encouraged to contact the OBO team in order to rectify this.

Ostensibly, the OBO project appears to have taken a number of steps to ensure that the transcription of the Sessions Proceedings has been accurate and the use of crowd sourcing to identify errors and problems ensures the accuracy of the $\mathrm{OBO}$ as an ongoing project. However, there are several potential concerns of which the researcher should be aware of when using the OBO and whilst safeguards have been put in place by the project, these reduce inaccuracies but do not eradicate them.

The first is the use of the double re-key approach to transcribing the Proceedings. This approach will undoubtedly highlight a number of the typographical errors caused directly by the transcribers. Typographical errors are inevitable and by using two different transcribers to input one trial report, it is assumed that these transcribers will make different errors, thereby highlighting mistakes in both transcriptions. This approach however does not address the potential for both transcribers to misread the original trial reports in the same way. The character and potential concerns regarding the Proceedings themselves have been addressed above but one concern for the modern day transcriber is not the substance of the Proceedings, but the form. Given the number of the Proceedings, there must be a number of these which have typographical or spelling errors. There has yet to be a comprehensive study as to the extent of these errors, however,

\footnotetext{
${ }^{2}$ http://www.oldbaileyonline.org/static/Project.jsp [Accessed $7^{\text {th }}$ January 2017].
} 
the researcher must assume these errors to be present. How does the transcriber address these errors? One approach is that the digitized versions of the Proceedings ought to be a true reflection of the original source as the source itself is greatly significant to the academic, if not to the family genealogist and the wider public. However, transcribing the Proceedings, warts and all, creates potential for problems in searching the OBO for specific keywords or names.

\section{Digitisation of Archives}

Traditionally, databases have been used as an interim aim, to create a tool through which future research can be conducted (Bradley, Short 2005, 3). This is certainly true of the OBO, which includes several statistical tools and searchable material for the researcher. When translating historical sources into databases, one of the most striking problems can be maintaining consistency between entries (Bradley, Short 2005, 4). This can be due to a number of factors such as the original source material being in different forms and layouts and more problematically, an inconsistency in spelling. The Proceedings create a further cause for inconsistency in the substance of the source itself, such as information being laid out in different parts of the Proceedings, or being absent.

A recent critique of the use of digitisation of historical sources suggested that this process removes the researcher for the source itself and prevents the reader from engaging with the nuances of the document as a whole (Ireland 2015, 132). This would certainly be the case were the Proceedings to be read as isolated trial reports as the Proceedings were a commercial as well as a quasi-official publication and, as such, much can be gleaned from reading individual trial reports within the context of the document as a whole. It is partly for this reason that the OBO attached a link to a photograph of the original page of the report to every trial record. However, only the specific page of the original document is attached to the trial transcript and so, reading a case within the context of the document as a whole is not straightforward. It is possible to see a Sessions Paper in its entirety on the $\mathrm{OBO}$ if the researcher searches through the 'browse' function by date (Hitchcock, Shoemaker 2006, 199). Whilst it is true that digitisation physically removes the researcher from the source, having images of the material allows for the reading of the document as a whole, including the reading of handwritten notes and annotations that may be written upon the document.

Digitising sources captures the substance of the text but not the form. It is possible through OBO date searches to see the layout of the Proceedings and an image of the original document (Hitchcock, Shoemaker 2006, 199). A digital image will not reveal the quality of the paper upon which the text is written or printed, nor will it always reflect the different uses of ink which may allow the research to draw some conclusions about the order in which handwritten notes are made upon the document. For example, in the case of letters sent during the 
eighteenth century, the quality of the paper may be indicative of the wealth of the writer or the esteem with which the writer holds the recipient. In the case of a document that has a number of entries from different authors, the level to which the ink may have faded may indicate the times at which the entries were made. The second of these examples does not impact upon the use of the OBO per se however, historians of newspaper and print may be interested in the quality of the paper used in the Proceedings and thus, a digital record will not reveal this information. Form aside, the content of archives, and the OBO in particular, are generally made available in their entirety for the researcher and such records will have the same advantages and limitations as paper-based sources (Hitchcock, Shoemaker, Winters 2011, 355).

A further concern with the digitisation of archives lies in the requirement to categorise information so as to allow searches, both qualitative and quantitative, of the material. This concern is greatly aligned with the wider issue of how historical documents can and ought to be read. There is a growing dialectic in thought surrounding the reading of historical material and within the wider humanities community, with the reading of big data (for example Moretti, 2005). The process of digitising any material and imposing searchable terms, inevitably involves the 'squeezing' of data into pre-defined categories (Bradley, Short 2005, 16). This process of categorisation will be explored further below.

\section{Data-Mining and the Key-Word Search}

Data-mining is a process whereby data can be searched to locate specific information. The best example of this would be using search terms to locate the number of times such terms appears across the Proceedings. This can be very successfully achieved for legal historians in particular as the Proceedings are very regular in form (Innes, Styles 1986, 389). There are however, potential pitfalls to data-mining. First, and as Ted Underwood has pithily summarised: 'in a database containing millions of sentences, full-text search can turn up twenty examples of anything' (cited in Robertson 2016, 1052). However, it is not the false positives that the researcher should be concerned with, it is the data that several searches will lose. The process of searching acts to filter out alternative hypotheses: 'If scholars use the wrong search terms, they literally misread their sources, and might not read them at all' (Robertson 2016, 1052).

To the legal historian, it may be tempting to agree that technical legal language makes data-mining searches unproblematic as largely legal language overcomes the problem of changing meanings and context of language in other sources (Robertson 2016, 1050). However, as shall be demonstrated below, when searching for fraud prosecutions, the formulaic use of such language in indictments as 'fraudulent', become deeply problematic. 


\section{SEARCHING FOR FRAUD OFFENCES WITHIN THE OBO}

The biggest challenge in using the OBO to research fraud offences comes in identifying which cases are to be defined as fraud. ${ }^{3}$ The OBO separates trials into a number of categories relating to offence: Breaking Peace, Damage to Property, Deception, Killing, Miscellaneous, Royal Offences, Sexual Offences, Theft and Violent Theft. These larger categories are then separated into sub-categories such as Deception-Fraud. When transcribing the Proceedings, the OBO team produced guidelines as to how the transcribers should categorise the trials into these offences. ${ }^{4}$ The transcribers were instructed to categorise the trial by the description of the indictment that was generally contained within the first paragraph of the trial report. If the indictment was not present or unclear, the transcribers were to categorise the offence based upon the testimonies of the witnesses within the Proceeding. Indictments were usually written to a formula. Due to this pro forma, these indictments do not contain much information (Shoemaker 1993, 147; $149 ; 155-156)$ but they should contain enough to roughly categorise the offence. This approach is, for many if not most offences, unproblematic as it is clear which offence applied. However, there are examples within the Proceedings of offences being described ambiguously. As shall be shown below, deception, fraud, embezzlement and forgery cases are the most common offences to have unclear indictments.

Upon first glance, the categorisation of offences within the OBO appears straightforward. There is a category of 'deception' and within this there is a subcategory of 'fraud'. However, these categories are unfortunately far less useful than they appear. The category of 'Deception' itself within the OBO includes forgery, fraud, perjury and bankruptcy offences. ${ }^{5}$ This categorisation appears to be somewhat of an afterthought of the OBO in that it is difficult to clearly link all of these offences. It is not the case that all of the offences are connected in that they require an element of 'deception'. For example, many bankruptcy offences involved people not surrendering themselves to Commissioners in good time, with no accusation of deception levelled against them. This categorisation has two fundamental flaws. There is no engagement with the ontological parameters of fraud offences or the interaction between these offences and other property offences. There is great overlap between crimes such as embezzlement, larceny, cheating by false pretences and other such offences (Beale 1892, 44) both in substance and in the manner in which they were prosecuted. Because of this,

\footnotetext{
${ }^{3}$ For an in-depth discussion on the laws surrounding fraud see Griffiths 2017.

${ }^{4}$ Proceedings of the Central Criminal Court 1834-1913. Welcome to the CC project Wiki! http://crimpleb.group.shef.ac.uk/wiki/pmwiki.php [Accessed ${ }^{\text {rd }}$ December 2014].

${ }^{5}$ Proceedings of the Central Criminal Court 1834-1913. Welcome to the CC project Wiki! http://crimpleb.group.shef.ac.uk/wiki/pmwiki.php [Accessed ${ }^{\text {rd }}$ December 2014].
} 
when searching fraud indictments, there are a number of false positives within the results identified by the OBO. If conducting simple statistical searches of the number of fraud offences, an inaccurate picture would be gleaned. For example, the 1819 prosecution of Alexander Lauder has been categorised by the OBO as a Deception-Fraud. The transposing of the trial by the shorthand writer is a more complete reflection of the indictment and at first glance does appear to be a fraud. However, a closer reading of the text reveals that this case was in fact relating to theft:

ALEXANDER LAUDER was indicted for that he, on the $30^{\text {th }}$ of August, being servant to David Vines, did, upon trust and confidence, deliver unto him four sacks of flour... his property, safely to keep the same to the use of the said David Vines; and that he, the prisoner, after such delivery, and while he was such servant, did feloniously withdraw himself from his said master, and go away with the said goods, with intent to steal the same, and defraud his said master thereof, contrary to the trust and confidence in him put by his said master, against the statute.

This indictment is clearly larceny firstly, because it stipulates 'intent to steal' and secondly, because it states the offence was a felony which statutory fraud offences were not.

A potential method to overcome these categorisation errors may be the use of search terms such as 'swindlers', 'cheats' or 'artful device', but again, we must be very careful to recognise that the shorthand writers themselves had so much influence over the reporting of the trials, that in most cases the reader hears not the voice of the actors within the trial, but the reporter. This does not result in such searches being useless as word searches may reflect the lexicon of the day. However, any statistical conclusions about the prosecution of fraud at the Old Bailey need to be significantly couched in the context of the Proceedings and their ultimate digitization.

\section{CONCLUSION}

This article has illustrated and assessed two of the reasons why there is a dearth of historical research into fraud offences. One reason is the ontological complexity of fraud offences, and the difficulties in tracing these offences through legal archives. The ontology of fraud will be discussed in detail in forthcoming publications, but this article has introduced how the complexity of definitions of fraud makes searching these offences in the archives deeply problematic. The majority of this article has focused on the potential pitfalls of legal archives for those wishing to research fraud offences in the early modern period. These archival challenges may go some way to explaining why researchers have largely avoided engaging in fraud research but it is hoped that this article has drawn attention to the more significant concerns for future historians of fraud. 
The primary focus of this article has been the Proceedings and this is largely because it is this archive which currently sits at the heart of much crime history research. The Proceedings have been digitised for over ten years and the interest in the OBO has only grown. More recently this archive has been linked to a broader crime history website, the Digital Panopticon ${ }^{6}$, which will undoubtedly stimulate even more interest in these records. This interest is to be encouraged as the sheer volume of information held within this archive allows for many avenues of research for academics, students, and genealogists. In light of the explosion of interest in Old Bailey records, this is the ideal time to reflect on the weaknesses as well as the immense strengths and positives of this set of records. It has been demonstrated how this archive is the Proceedings are not complete, nor is it unproblematic and how it is only through triangulating cases from other courts records with the Proceedings, that we see which cases are missing. Until all court records are digitised and are able to be cross-tabulated, it is only through the employment of a methodology of close reading of cases that missed records will be identified. This is not to say that other forms of research including quantitative searches using the search tools available through the OBO should not be employed. For research over longer time-periods and concerning larger case-samples, a close-reading approach will not always be possible, or indeed desirable. Missing data plagues all researchers in one form of another and acknowledging that the Proceedings are not an absolute complete record of all hearings at the Old Bailey does not undermine. However, these missing cases and lack of much legal detail should not dissuade researchers from drawing on what remains the most detailed and colourful record collection of seventeenth to nineteenth century English court records.

\section{BIBLIOGRAPHY}

Archer, Dawn. 2014. "Historical Pragmatics: Evidence from the Old Bailey". Transactions of the Philological Society 112 (2): 259-277.

Beale, Joseph H. 1892. "The Borderland of Larceny”. Harvard Law Review 6 (5): 244-256.

Bradley, John. Harold Short. 2005. "Texts into databases: the evolving field of new-style prosopography". Literary and Linguistic Computing 20 (1): 3-24.

Devereaux, Simon. 1996. "The City and the Sessions Paper: "Public Justice" in London 17701800". Journal of British Studies 35 (4): 466-503.

Devereaux, Simon. 2007. "From Sessions to Newspaper? Criminal Trial Reporting, the Nature of Crime, and the London Press, 1770-1800". The London Journal 32 (1): 1-27.

Eiseman, Jason et al. 2016. "Litchfield Unbound: Unlocking Legal History with Metadata, Digitization, and Digital Tools". Law and History Review 34 (4): 831-855.

Foreman-Peck, James. 1995. "Sleaze and the Victorian Businessman". History Today 45 (8): 5-8.

Gallanis, Thomas P. 2006. "The Mystery of Old Bailey Counsel”. Cambridge Law Journal 65 (1): 159-173.

\footnotetext{
${ }^{6}$ https://www.digitalpanopticon.org/ [Accessed $28^{\text {th }}$ December 2018].
} 
Griffiths, Cerian Charlotte. 2014. "The Prisoners' Counsels Act 1836: Doctrine, Advocacy and the Criminal Trial". Law, Crime and History 2: 28-47.

Griffiths, Cerian Charlotte. 2017. Prosecuting Fraud in the Metropolis, 1760-1820. Unpublished doctoral thesis. Liverpool: University of Liverpool.

Hay, Douglas. 2006. "Writing about the Death Penalty". Legal History 10: 35-51.

Hitchcock, Tim. Robert Shoemaker. 2006. "Digitising History from Below: The Old Bailey Proceedings Online, 1674-1834”. History Compass 4 (2): 193-202.

Hitchcock, Tim. Robert Shoemaker. James Winters. 2011. "Connected histories: a new web search tool for British historian". The Journal of the Historical Association 96: 354-356.

Innes, Joanna. John Styles. 1986. "The Crime Wave: Recent Writing on Crime and Criminal Justice in Eighteenth-Century England". Journal of British Studies 25 (4): 380-435.

Ireland, Richard. 2015. "Why everything we know about criminal justice history is wrong". Law, Crime and History 5 (1): 130-142.

King, Peter. 2009. "Making Crime News: newspapers, violent crime and the selective reporting of the Old Bailey trials in the late eighteenth century". Crime, History and Society 13 (1): 91-116.

Langbein, John. 1978. "The Criminal Trial before the Lawyers". The University of Chicago Law Review 45 (2): 263-316.

Langbein, John H. 1999. "The prosecutorial origins of defence counsel in the eighteenth century: the appearance of solicitors". Cambridge Law Journal 58 (2): 314-365.

Levi, Michael. 1987. Regulating fraud: white-collar crime and the criminal process. London and New York: Tavistock Publications.

McGowen, Randall. 2007. "Managing the Gallows: The Bank of England and the Death Penalty, 1797-1821". Law and History Review 25 (2): 241-282.

Moretti, Franco. 2005. Graphs, Trees and Maps: Abstract Models for Literary History. London and New York: Verso.

Proceedings of the Central Criminal Court 1834-1913. Welcome to the CC project Wiki! h t t p : // crimpleb.group.shef.ac.uk/wiki/pmwiki.php.

Robb, George. 1992. White-Collar Crime in Modern England. Financial Fraud and Business Morality, 1845-1929. Cambridge: Cambridge University Press.

Robertson, Stephen. 2016. "Searching for Anglo-American Digital Legal History". Law and History Review 34 (4): 1047-1069.

Shoemaker, Robert B. 1993. "Using Quarter Sessions Records as Evidence for the Study of Crime and Criminal Justice". Archives 20 (90), 145-157.

Shoemaker, Robert B. 2008. "The Old Bailey Proceedings and the Representation of Crime and Criminal Justice in Eighteenth-Century London”. Journal of British Studies 47: 559-580.

Sindall, Rob. 1983. "Middle Class Crime in Nineteenth-Century England". Criminal Justice History 4: $23-40$.

Taylor, James. 2006. "Creating Capitalism: Joint-stock enterprise in British politics and culture, 1800-1870". The Royal Historical Society.

Tomasic, Roman. 2011. "The financial crisis and the haphazard pursuit of financial crime". Journal of Financial Crime 18 (1): 7-31.

Wilson, Sarah. 2006. "Law, Morality and Regulation: Victorian Experience of Financial Crime". British Journal of Criminology 46 (6): 1073-1090. 
Cerian Charlotte Griffiths

\title{
BADANIE OSIEMNASTOWIECZNYCH SPRAW DOTYCZĄCYCH OSZUSTWA PROWADZONYCH W OLD BAILEY: REFLEKSJE NA TEMAT AKT SĄDOWYCH, ARCHIWÓW I DIGITALIZACJI
}

\begin{abstract}
Streszczenie. Artykuł ma na celu przedstawienie spostrzeżeń i wskazówek pomocnych badaczom zajmującym się przestępstwem oszustwa w Wielkiej Brytanii w osiemnastym i dziewiętnastym stuleciu. Spostrzeżenia te wyjaśniają przyczyny, dla których brakuje historycznych badań nad przestępstwem oszustwa. Są one tak ontologiczne, jak i metodologiczne. Definicje praw dotyczących oszustwa są złożone i trudne do zidentyfikowania, zaś jedno z najbardziej dostępnych archiwów, Akta Sesyjne Old Bailey (Sprawozdania), muszą być wykorzystywane przez badaczy z ostrożnością. W artykule wskazano historyczne okoliczności powstania Sprawozdań i zastosowano tę wiedzę do badań nad przestępstwem oszustwa, które w świetle powyższych ustaleń, wymagają wyjątkowego podejścia metodologicznego.
\end{abstract}

Słowa kluczowe: Oszustwo; Old Bailey; digitalizacja; historia prawa; metodologia. 